\title{
The training of pharmaceutical professionals and their insertion in the unified health system (SUS): an integrative literature review
}

\section{Luciano Júnior da Silva Vasconcelos'; Emilly Tainá Batista da Silva²; Barbara Rafaelly da Silva Lacerda $^{3}$; Emivaldo Batista da Silva ${ }^{4}$; Allyson Rodrigo de Oliveira Lopes ${ }^{5 *}$; Emanuella Barros de Souza Oliveira Álvares ${ }^{6}$}

\author{
1, 3, 4 Department of Pharmacy, Pharmacy Sciences Center, University Center of Vitória de Santo Antão (UNIVISA), Vitória de Santo \\ Antão, Brazil \\ 2 Department of Biomedicine, Biomedical Sciences Center, University Center of Vitória de Santo Antão (UNIVISA), Vitória de Santo Antão, \\ Brazil \\ 5, 6 Department of Biology, Biological Sciences Center, Professor of the Full Degree Course in Biology of the University Center of Vitória de \\ Santo Antão (UNIVISA), Vitória de Santo Antão, Brazil
}

E-mail adresses: luc.filho1276@gmail.com (Luciano Júnior da Silva Vasconcelos), emilly.taina@hotmail.com (Emilly Tainá Batista da Silva), barbaralacerda.2017a@gmail.com (Bárbara Rafaelly da Silva Lacerda), emivaldobatista4@gmail.com (Emivaldo Batista da Silva), allysonlopes85@gmail.com (Allyson Rodrigo de Oliveira Lopes), emanuelabarros@univisa.edu.br (Emanuella Barros de Souza Oliveira Álvares).

*Corresponding author

\section{To cite this article:}

Vasconcelos, L.J.S.; Silva, E.T.B.; Lacerda, B.R.S.; Silva, E.B.; Lopes, A.R.O; Álvares, E.B.S.O. The training of pharmaceutical professionals and their insertion in the unified health system: an integrative literature review. International Journal of Sciences. Vol. 1, No. 3, 2021, pp. 125-130. ISSN 2763-5392

Received: 05 15, 2021; Accepted: 05 15, 2021; Published: 05 24, 2021

\begin{abstract}
In the 1980s, the role of pharmacists in society became a topic of discussion in the category, necessarily accompanied by the discussion on pharmaceutical education. The present study aimed to conduct an integrative review of the scientific literature in order to understand the training of the pharmaceutical professional and its insertion in public health. A survey of the literature was carried out from January to December 2019, in the PERIODIC CAPES and Google Scholar databases. It was found that few studies offer an analysis in relation to the training of pharmaceutical professionals and their insertion in public health. It is concluded, even if synthetically, it is noted that Brazilian public health, over many years, had to adapt the need of the pharmaceutical professional, even as a form of recognition, going back to the pestilences and atrocities experienced, whose pharmaceutical performance was necessary, solidary and essential.
\end{abstract}

Keywords: National Pharmaceutical Assistance Policy. National Medicines Policy. Pharmaceutical Assistance Services. Unified Health System

\section{Introduction}

Since the years 2008 when the Family Health Support Center (NASF) was established, the expansion of primary care activity could be observed, thus resulting in the incorporation of the pharmacist in this multi-professional scenario. From this event comes the opportunity to implement the work process involving access and commitment, as well as awareness about the rational use of medicines (NAKAMURA, 2016).

However, difficulties related to the recognition and acceptance of the interventions of the pharmacists have been noted since then. Records indicate the ascendancy of isolation that the pharmacist suffers in the scope of primary care. However, there are discreet perspectives of strengthening their integration with the team, being incited by institutional and normative changes at the national level (BARBERATO, 2019).

Among the advances and setbacks that followed during the 30-year history of the Unified Health System, it was observed that the movement that instituted the health reform offered pharmaceutical assistance (PA). A 
reorientation was necessary in order to deal directly with topics considered relevant, such as: technological development, industrial production and ethical regulation (OLIVEIRA, 2017). From this event, the idea that two operational cells are fundamental for the viability of pharmaceutical services and contributions in Public Health become evident: the implementation of a technical management of the drug and a management of care.

From this implementation, the consolidation of an innovative model of pharmaceutical service is demonstrated (PEREIRA, 2015). Considering the various studies that express the need for the implementation of articulated and synchronized actions between the various activities that compose the training and performance of the pharmaceutical professional and its insertion in public health that should be understood as measures implemented by the State to ensure the physical, mental and social well-being of the population, it becomes relevant the development of an integrative review of the literature (CARVALHO,2017).

The present study aimed to conduct an integrative review of the scientific literature in order to understand the training of the pharmaceutical professional and its insertion in public health.

\section{Methodology}

A survey of the literature was carried out from January to December of 2019, in the periodic databases CAPES and Google Academics.

The descriptors used were as follows: "National Pharmaceutical Assistance Policy" AND "National Drug Policy" AND "Pharmaceutical Care Services" AND "Unified Health System" in both databases.

For the study, 18 articles were selected and included according to the eligibility criteria according to Figure 1.

The inclusion criteria were: articles in English, Spanish and Portuguese, published in the last five years involving the training of the pharmaceutical professional and their insertion in public health.

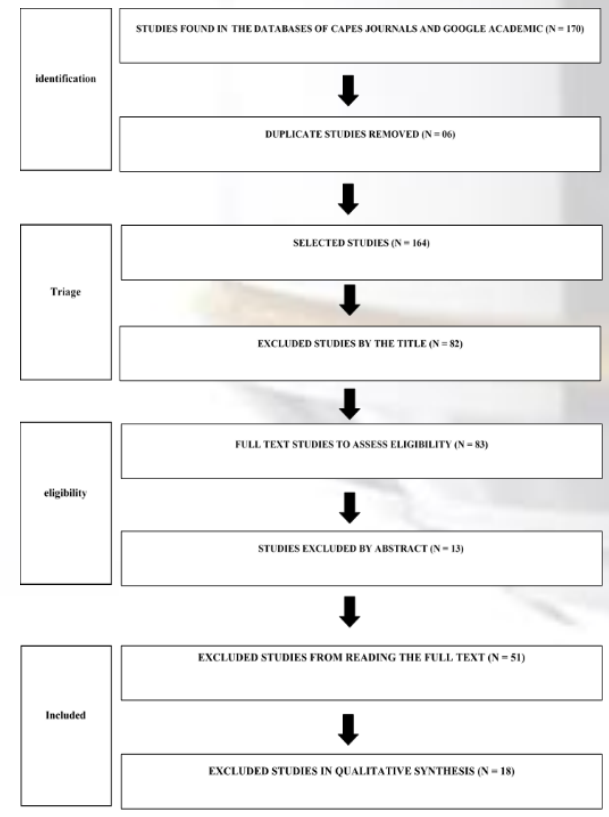

Figure 1. Flowchart and selection and inclusion criteria of studies

\section{Results and Discussions}

While public health continues in a constant and encouraging improvement, it is perceived that the pharmaceutical professional becomes an essential part of the multidisciplinary team, while providing an opportunity for a formal and ethical parameter, allowing managers of health programs to implement habits that are efficient and contributory in order to achieve the purposes listed and, above all, that can have as results a network of services accessible to the population (BARBERATO, 2019). One of the strategies that allow the presence of the pharmacist in his staff is the Family Health Support Center (FHSC/NASF) (BARROS, 2017). Unfortunately, there is an absence of knowledge among the professionals who are part of the NASF, as well as family health teams, including the pharmacists themselves, about the attributes that should be emphasized by a multidisciplinary team. The process as a whole is not yet with concrete definitions and structuring's (NAKAMURA, 2016).

The number of pharmacists present in the frameworks of the Unified Health System (UHS/SUS), although scarce, especially regarding the dispensing of medicines in the UBS, is essential to ensure a pleasant interpersonal relationship, with looks aimed at the success of team interventions (ALENCAR,2017). Since 1998, when the National Medicines Policy was implemented, it was observed the progressivity of promoting accessibility to the necessary medicines (MELO, 2017).

According to Oliveira (2017), some determinations are established for the rational use of medicines. Briefly, the need to use it; prescribed the medicine due thereafter. The latter is a priority, following the projects of efficacy and safety. Thus, the pharmaceutical professional is a strategic point for triggering a complete health promotion, looking at the criteria, which are: responsible orientation and wide population reach (CARVALHO,2018).

Although recent, Pharmaceutical Care (PC) has emerged as a watershed in the pharmaceutical field, considered as a care aggregation to health care networks (RAS) and not an element included in clinical management (LEITE, 2018). The relationship of the pharmacist with the user of the system needs to be clearly evidenced. Acting in this usually can be challenging for pharmacists due to professional limitation for years in the technical management of the drug (PEREIRA, 2015).

At the moment when Brazil appears in the fourth position in the world ranking of drug consumption, the number of commercial pharmacies rises noticeably. In the meantime, it is essential to requalify pharmacies and drugstores as an environment of health care. The lack of autonomy to deal directly with the consumer, as well as the compulsive direction of some pharmacies to deprive themselves of the development of administrative and administrative activities, are priorities that need to be abolished (BIZ,2018); (OLIVEIRA, 2017).

Bermudez (2018), says that when we pay for contemporaneity, we note that with the advent of the citizen constitution, the SUS and universal access to health, the Sanitary Reform comes to light, thus building a "just country, equitable and with social justice". Among the principles of the integrality of the system, there is the reorienting of 
Pharmaceutical Assistance.

The longing for the pharmacy course has been frequent and growing, especially in private institutions, however the economic situation of the country calls into question the hopes of undergraduates, who obtain doubts about employability after the completion of the course (BATISTA, 2015). After choosing the career, it is of paramount importance to aim at the area of possible performance, among which are: food; clinical analyses; education; pharmacy; hospital pharmacy and/or clinic; management; industrial pharmacy; and toxicology (SILVA, 2019).

Since the insertion of the pharmaceutical professional in Primary Care, also with emphasis on the Family Health Strategy (ESF) new benefits to the population were noticeable, due to the notorious contribution in the pharmacological scope (NUNES, 2017).

Unfortunately, the number inserted is still simple in the face of the constant need for an "adequate care in the development of pharmaceutical actions", (SILVA, 2019).

\section{Conclusions}

The analyses carried out about the implementation of articulated and synchronized actions between the various activities that compose the training of the pharmaceutical professional and their insertion in public health allowed the recognition, pertinence and magnitude of the pharmacist's performance, identifying the difficulties, obstacles and potentialities experienced by professionals and the Unified Health System.

\section{Acknowledgements}

I express my sincere and profound thanks to God, the eternal father, for the opportunity to write this enriching draft for public health purposes whether at local, national or international level. To the collaborators who are here as coauthors, my eternal gratitude. The mutuality that permeates the coexistence between health professionals' results in a multidisciplinary team resistant, committed and responsible to the public cause in the scope of assistance to the greatest individual good that may exist: health.

\section{References}

[1] ALENCAR, Tatiane de Oliveira Silva; PAIM, Jairnilson Silva. Reforma Sanitária Brasileira e políticas farmacêuticas: uma análise dos fatos produzidos entre 2003 e 2014. Saúde debate, Rio de Janeiro, v. 41, n. spe3, p. 45-59, set. 2017.

[2] BARBERATO, Chaves. L. et al. O farmacêutico na atenção primária no Brasil: uma inserção em construção. Universidade de Brasília. Programa de Pós - Graduação em Saúde Coletiva. Asa Norte, Brasília - DF. Revista Ciência \& Saúde Coletiva. Rio de Janeiro, v. 24, n.10, 2019.

[3] BARROS, Santos. E.A.D. Inserção dos farmacêuticos nos centros de atenção psicossocial no estado da Bahia. 2017. $16 \mathrm{f}$. Monografia (especialista em saúde mental e atenção básica) -
Escola Bahiana de Medicina e Saúde Pública. 2017.

[4] BATISTA, Siqueira -. R. (Bio) ética e Estratégia Saúde da Família: mapeando problemas. São Paulo. Brasil. Revista Brasileira Saúde e Sociedade, vol. 24, n. 1, 2015.

[5] BERMUDEZ, Zepeda. J.A. Assistência Farmacêutica nos 30 anos do SUS na perspectiva da integralidade. Rio de Janeiro. Brasil. Revista Ciência \& Saúde Coletiva, v. 23, n. 6, 2018.

[6] BIZ, Ferreira. C. U. N. A importância da atuação do profissional farmacêutico na saúde mental. Rio de Janeiro. Brasil. Revista Semioses, v. 12, n. 4, 2018.

[7] CARVALHO, Nobre. M. Necessidade e dinâmica da força de trabalho na Atenção Básica de Saúde no Brasil. Rio de Janeiro. Brasil. Revista Ciência \& Saúde Coletiva, v. 23, n. 1, 2018.

[8] CARVAlHO, M., Álvares, J., Costa, K., Guerra Junior, A., Acurcio, F. de A., Costa, E., Guibu, I., Soeiro, O., Karnikowski, M., \& Leite, S. (2017). Força de trabalho nos serviços farmacêuticos da atenção primária à saúde do SUS, Brasil. Revista De Saúde Pública, 51 (suppl.2), 16s.

[9] LEITE, Silvana Nair et al. Ciência, Tecnologia e Assistência Farmacêutica em pauta: contribuições da sociedade para a $16^{\mathrm{a}}$ Conferência Nacional de Saúde. Ciênc. saúde coletiva, Rio de Janeiro, v. 23, n. 12, p. 4259-4268, dez. 2018.

[10] MELO, Daniela Oliveira de; CASTRO, Lia Lusitana Cardozo de. A contribuição do farmacêutico para a promoção do acesso e uso racional de medicamentos essenciais no SUS. Ciênc. saúde coletiva, Rio de Janeiro, v. 22, n. 1, p. 235-244, jan. 2017.

[11] NAKAMURA, Carina Akemi; LEITE, Silvana Nair. A construção do processo de trabalho no Núcleo de Apoio à Saúde da Família: a experiência dos farmacêuticos em um município do sul do Brasil. Ciênc. saúde coletiva, Rio de Janeiro, v. 21, n. 5, p. 1565-1572, maio 2016.

[12] NUNES, Alandesson Sousa et al. A importância do farmacêutico na promoção de estratégias em unidades básicas de saúde de Bacabal - MA. Revista uningáreview, [s.1.], v. 29, n. 3, mar. 2017. Issn 2178-2571.

[13] OLIVEIRA, Naira Villas Boas Vidal de et al. Atuação profissional dos farmacêuticos no Brasil: perfil sociodemográfico e dinâmica de trabalho em farmácias e drogarias privadas. Saude soc., São Paulo, v. 26, n. 4, p. 11051121, dez. 2017.

[14] PEREIRA, Nathália Cano; LUIZA, Vera Lucia; CRUZ, Marly Marques da.Serviços farmacêuticos na atenção primária no município do Rio de Janeiro: um estudo de avaliabilidade. Saúde debate, Rio de Janeiro, v. 39, n. 105, p. 451-468, jun. 2015.

[15] SILVA, Maria Edineide da; TORRES, Vivian Mariano. A importância do farmacêutico presente na estratégia saúde da família (ESF). Revista Brasileira de Educação e Saúde. v.9, n.4, p. 27-33, 2019.

[16] SILVA, Renata Pimentel da; ALVES, Simone Salviano. Aprendendo a ser farmacêutico: o processo de formação profissional. Congresso Brasileiro de Ciências da Saúde. Campina Grande, 2018.

[17] SILVA, Roberta de Faria; TORMIN, Consuelo Vaz; PAULA, 
Victor Gomes de. Percepção de graduandos do curso de farmácia sobre a atuação profissional no mercado farmacêutico. Núcleo Interdisciplinar de Pesquisa - Centro Universitário de Desenvolvimento do Centro Oeste. Goiás, 2019.

[18] SILVA, Alamisne Gomes da; LIMA, José Gildode; LIRA, Aline Cavalcante de. Atuação do farmacêutico nos núcleos de apoio à saúde da família: uma contribuição para o fortalecimento da estratégia de saúde da família. Revista de Atenção Primária de Saúde. Juiz de Fora, v.19, n.1, 2017. 